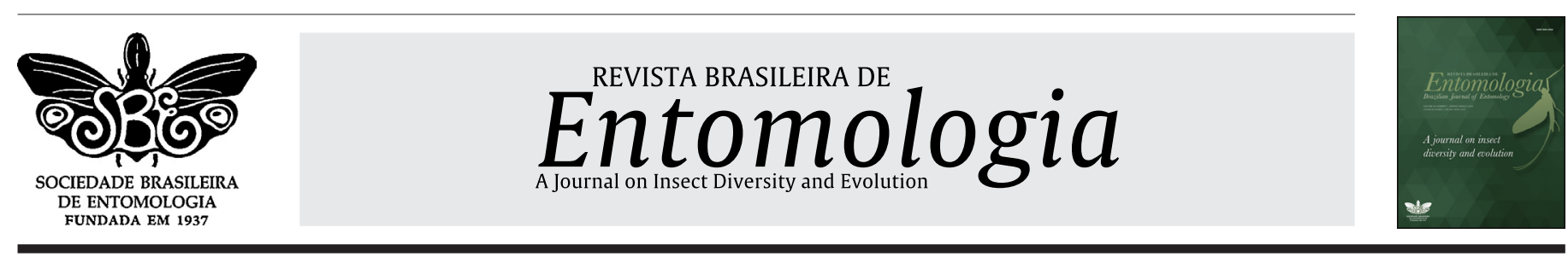

\title{
The influence of agricultural occupation and climate on the spatial distribution of Plusiinae (Lepidoptera: Noctuidae) on a latitudinal gradient in Brazil
}

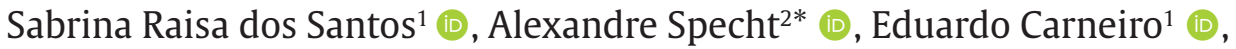 \\ Mirna Martins Casagrande ${ }^{1}$ (D)
}

${ }^{1}$ Universidade Federal do Paraná, Departamento de Zoologia, Laboratório de Estudos de Lepidoptera Neotropical, Curitiba, PR, Brasil. ${ }^{2}$ Embrapa Cerrados, Laboratório de Entomologia, Planaltina, DF, Brasil.

\section{A R T I C L E I N F O}

\section{Article history:}

Received 16 October 2020

Accepted 17 January 2021

Available online 24 February 2021

Associate Editor: Thamara Zacca

\section{Keywords:}

Abundance

Assemblage structure

Looper moths

Pest species

\begin{abstract}
A B S T R A C T
Studies have reported the presence of certain Plusiinae species in both natural and agricultural landscapes, but their turnover in association with agricultural activities remains unexplored. Aiming to understand how the assemblages of Plusiinae are structured by agricultural occupation and climate, this study used automated light traps sampled moths in 18 sites in Brazil, across a broad latitudinal gradient. Our data has demonstrated that climate variables prevails as the most important variables influencing both the composition of Plusiinae and the abundance of its dominant species Chrysodeixis includens. On the other hand, the lack of significance found for the effect of variables representing agricultural occupation evidences that pest species are present both in agricultural and natural ecosystems, also sharing similar abundances at those locations. In other words, instead of following a gradient of agricultural occupation (e.g. crop sizes around sample sites) the composition of these extremely polyphagous insects is more clearly shaped by the latitudinal gradient, in which temperature and precipitation are better predictors. Thus, in contrary to our expectations, pest species inhabits both natural and agricultural landscapes at similar latitudinal sites, probably due to their wide polyphagy spectrum. These results can be used in management and monitoring programs of pest species in South America, since the local abundance variation and species composition can be more reliable predicted by changes in climate conditions.
\end{abstract}

\section{Introduction}

It has been shown that lepidopteran assemblages respond to a variety of modifications in vegetation structure (Dover and Settele, 2009; Ribeiro et al., 2012) dictated by their habitat requirements, for instance the availability of host plants for their larvae (Munguira et al., 2009; Silva-Brandão et al., 2016). Most studies on this subject have been carried out in natural environments, but the effects of agricultural activities on the structure of lepidopteran assemblages have not been as extensively explored. It is known, for example, that communities inhabiting natural environments are highly influenced by their biomes or dominant type of vegetation in terms of composition (Oliveira et al., 2017). Likewise, climatic factors such as temperature and precipitation are also known to restrict the distribution of many species of arthropods (Robinet and Roques, 2010), thus playing a major rule on local species composition and structure.

The transformation of natural habitats into agricultural ecosystems results in local assemblages being re-structured. For instance, species associated with disturbed environments (e.g. generalists or those

\footnotetext{
* Corresponding author.

E-mail: alexandre.specht@embrapa.br (A. Specht)
}

with high dispersal ability) may become dominant, suppressing the populations of species commonly found in preserved environments (Rambaldi and Oliveira, 2003). Additionally, since agricultural occupation usually reduces the availability of shelters for predators (Primavesi et al., 2007), populations of generalist species tend to go unchecked.

Semiloopers, or looper moths, are one example of particularly dominant insects in the agricultural landscape. Some of them are extremely polyphagous moths and agricultural pests of native and exotic plants (Wagner et al., 2011), including major annual crops like soybeans, corn, wheat, rice, sunflower and greenery (Lafontaine and Poole, 1991; Baldin et al., 2014; Specht et al., 2015, 2019). For example, Chrysodeixis includens (Walker, [1858]) and Trichoplusia ni (Hübner, [1803]), stand out as one of the main pest species of soybean and cabbage, respectively, thus being abundantly sampled across many distinct places thorough the Americas (Poole 1989, Lafontaine and Poole, 1991). On the other hand, other several species can only be found in more restrict natural habitats, and their distribution in South America remains poorly known. Therefore, both natural and agricultural landscapes may harbor very distinct composition of Plusiinae assemblages, thus presenting a 
suitable scenario to study whether the climate or the landscape itself are better predictors of looper moths abundance and composition.

Aiming this goal, this study sampled assemblages of looper moths across a wide latitudinal gradient in Brazil, comprising at each location two contrasting landscapes dominated by agricultural occupation or native vegetation. We hypothesized that agricultural occupation (e.g. size of crop species plantations) are better predictors of assemblage structure of Plusiinae than climate itself, once agricultural landscapes tend to be dominated by pest species while natural landscapes tend to harbor a more diverse and equally abundant fauna. Because the soylooper moth ( $C$. includens) showed to be the dominant species at almost every sample site, we additionally tested for the predictive power of the same parameters in its abundance.

\section{Materials and methods}

\section{Collection areas}

Distributed along a latitudinal gradient from $-2^{\circ}$ to $-31^{\circ}$, a total of 11 Brazilian municipalities were sampled monthly between June 2015 and May 2016, during an atypical, strong El Niño episode (NOAA, 2020). However, in a few of these municipalities, two traps were placed, to represent variation in the local agricultural or native landscape. They were set at least $2 \mathrm{~km}$ apart from each other to avoid mutual interference. A total of 18 sampled sites were considered in our data, each representing a unique agricultural and native landscape coverage (Table 1, Figure 1).

The sample sites represented agricultural landscape where soybean and corn as major crops, alternating with pasture and native (or noncultivated) areas. During this experiment, the sampled sites were not sprayed with insecticides but it was not possible to obtain the cultural treatments made in the previous period. These crop fields also do not offer food resources (nectar) for moths.

The native hostplants of Neotropical Plusiinae are still poorly known. The sample sites predominantly covered by native vegetation offer abundant and rich nectar resources, especially during the spring. These sites represent natural or semi-natural vegetation of five distinct South American biomes: the Amazon, Caatinga, Cerrado, Atlantic Forest and Pampa (IBGE, 2004) (Figure 1). Thus, the sample sites also represent a broad variation in climate, for instance average temperature (from 18 to $26^{\circ} \mathrm{C}$ ), and annual precipitation (from 500 to $1900 \mathrm{~mm}$ ).

\section{Collection method}

Sampling was carried out in each locality using light traps. The standardized Pennsylvania type traps (Frost, 1957) were used, all supplied with BL T8 15W (Mark Tovalight) fluorescent lamps, with a range of 290 to 450 nanometers in wavelength and a peak at nearly 340 nanometers. They were automatically connected with a luminosity sensor from the evening twilight until the next morning. The lower part of each trap was furnished with a plastic cone $(32 \mathrm{~cm}$ at the greatest diameter and $16 \mathrm{~cm}$ at the smallest diameter), to which a plastic vessel containing $3 \mathrm{~L}$ of $96 \mathrm{GL}$ ethyl alcohol was fixed. The lower part of the collection vessel was $3 \mathrm{~m}$ high above the soil.

During every new moon phase, traps were kept active for five nights, for a total of 12 collection events, over one year. To reduce the stochastic effects on trap efficiency (e.g. rains and winds), only two of the five sampling nights were chosen, eliminating those with the fewest numbers of individuals captured. Most specimens were preserved in 96GL alcohol, with a few being dried, mounted and deposited in the Insect Collection of Embrapa Cerrados and Entomological Collection Pe. Jesus Santiago Moure, Departamento de Zoologia, Universidade Federal do Paraná. Species identification used the reference collection of the Embrapa Cerrados and specialized bibliography (e.g. Eichlin and Cunningham, 1978; Lafontaine and Poole, 1991; Barbut, 2008).

Climate data was taken from WorldClim (version 1.4) (Hijmans et al., 2006). The agricultural occupation data was measured using satellite images, considering the extent of the cultivated and native areas, and later identified "in loco" of the crop species. The size of crop and native areas were calculated by drawing polygons inside a 400-m radius buffer, using Google Earth Pro (version 1.3.31.5).

\section{Statistical analysis}

To recognize the general patterns in the Plusiinae assemblages, a canonical correspondence analysis (CCA) was generated. We used a log-transformed multivariate abundance data of Plusiinae species

Table 1

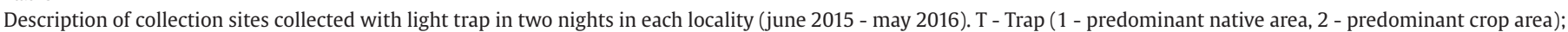

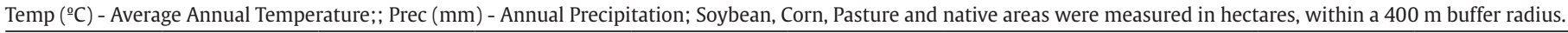

\begin{tabular}{|c|c|c|c|c|c|c|c|c|c|}
\hline Local & $\mathrm{T}$ & Lat & Long & Temp & Prec & Soybean & Corn & Pasture & Native \\
\hline Alegre & 1 & -20.37 & -41.06 & 23.9 & 1094 & 0.00 & 0.05 & 0.00 & 10.54 \\
\hline Alegre & 2 & -20.75 & -41.49 & 19.6 & 1321 & 0.00 & 0.06 & 8.13 & 0.37 \\
\hline Bage & 1 & -31.32 & -54.00 & 17.8 & 1348 & 0.00 & 0.00 & 14.35 & 1.06 \\
\hline Bage & 2 & -31.35 & -54.02 & 18.5 & 1385 & 0.00 & 0.00 & 2.09 & 13.55 \\
\hline Londrina & 1 & -23.20 & -51.18 & 21.9 & 1280 & 6.00 & 0.00 & 2.74 & 0.00 \\
\hline Londrina & 2 & -23.20 & -51.18 & 21.9 & 1280 & 2.56 & 1.23 & 1.60 & 7.59 \\
\hline Passo & 1 & -28.23 & -52.40 & 18.2 & 1732 & 2.00 & 0.25 & 0.51 & 2.26 \\
\hline Passo & 2 & -28.23 & -52.40 & 18.2 & 1732 & 0.25 & 0.03 & 0.09 & 9.67 \\
\hline Petrolina & 1 & -9.07 & -40.17 & 24.4 & 514 & 0.00 & 0.00 & 0.00 & 2.65 \\
\hline Petrolina & 2 & -9.14 & -40.30 & 24.6 & 464 & 0.00 & 0.04 & 1.02 & 5.10 \\
\hline Planaltina & 1 & -15.60 & -47.71 & 24.5 & 1479 & 1.59 & 0.10 & 0.48 & 0.00 \\
\hline Planaltina & 2 & -15.61 & -47.75 & 24.6 & 1447 & 0.41 & 0.00 & 0.35 & 11.60 \\
\hline Rio & 1 & -10.03 & -67.63 & 26.2 & 1875 & 4.38 & 4.84 & 0.00 & 1.43 \\
\hline Rio & 2 & -10.03 & -67.70 & 25.8 & 1887 & 0.00 & 0.00 & 6.63 & 10.95 \\
\hline Santarem & 2 & -2.70 & -54.57 & 27.1 & 1674 & 1.45 & 2.41 & 0.00 & 9.47 \\
\hline Sinop & 2 & -11.88 & -55.60 & 24.6 & 1962 & 0.76 & 0.00 & 0.00 & 6.61 \\
\hline Uberaba & 1 & -19.65 & -47.97 & 21.4 & 1519 & 0.68 & 0.97 & 6.15 & 0.00 \\
\hline Uberaba & 2 & -19.66 & -47.96 & 21.2 & 1530 & 0.12 & 0.00 & 4.80 & 11.39 \\
\hline
\end{tabular}




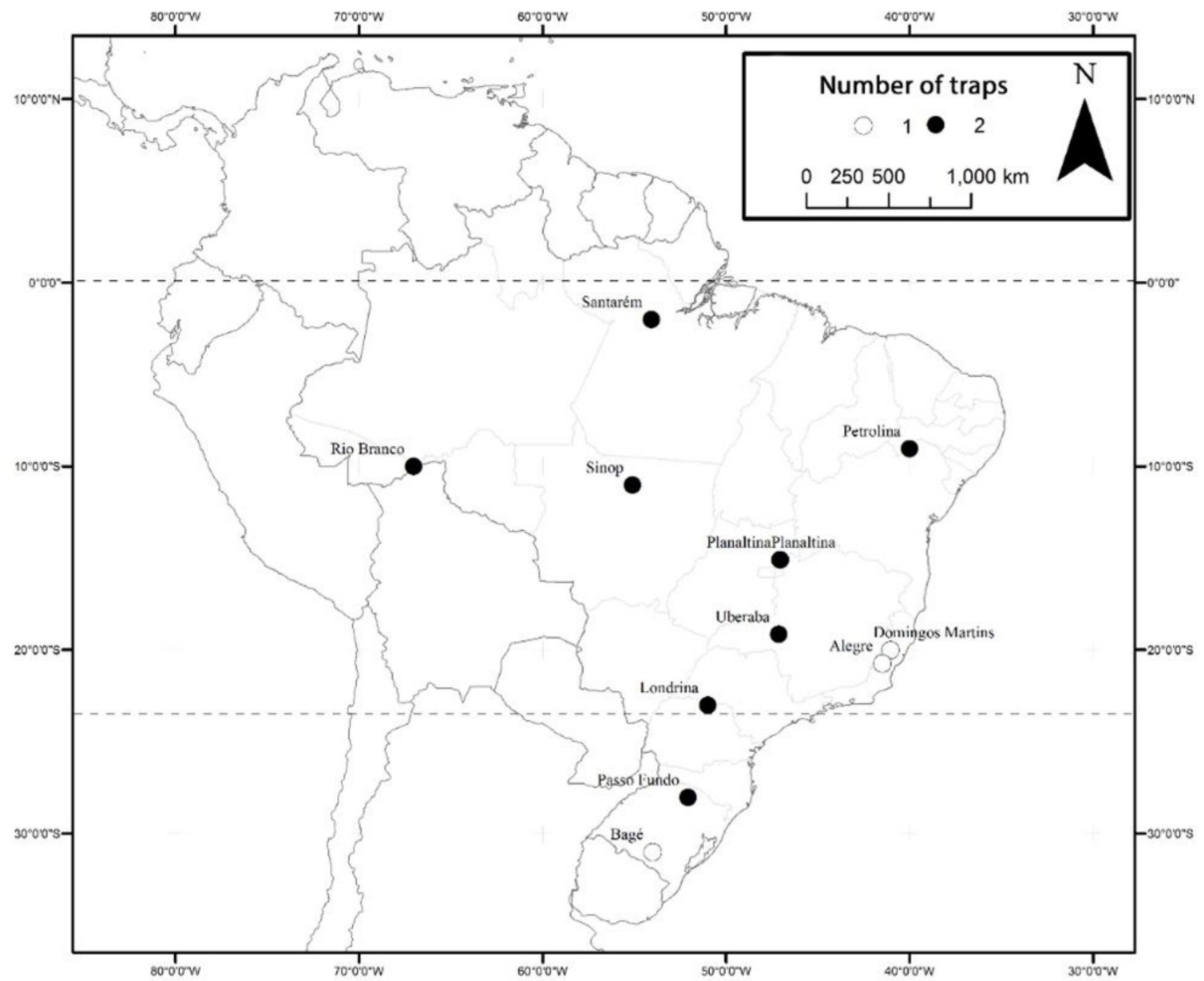

Figure 1 Geographical location of sampling sites. The color of the dots distinguishes the locations with one (white) or two (black) light traps.

as response for a matrix containing four landscape and two climatic variables: annual average temperature, annual precipitation, and number of hectares of soybean, corn, pasture, and native areas, calculated in a $400 \mathrm{~m}$ buffer radius.

Later, the axes produced by the CCA were regressed against each of the predictors in order to identify which variables are more strongly correlated to the full assemblage ordination.

Because we found that $C$. includens was the most dominant species in our data, and present in all our sample sites, we also tested the predictive power of the same variables on its local abundance. These models were built on a negative binomial distribution because species' abundance did not have a normal distribution. The agricultural occupation, climatic metrics and a null model were tested as predictor variables, to finally produce seven models in total. The models were created individually for each variable, since the simultaneous use of several variables tend to decrease the explanatory power of the models. Thus, the predictive power of each variable was directly compared using the Corrected Akaike Information Criterion (AICc). Models showing a difference in value (even from 0 to 2 ) imply a predictive capacity (Burnham and Anderson, 2003). The AICc values enable the calculation of the weight of evidence for each model, from 0 to 1 . As all the variables need to express some predictive value, the variables showing distinctly higher values than those generated by the null model are considered significant predictors. These models were produced exclusively to the most abundant species, since variation found in rare species is too small to produce reliable predictions. All the models were generated in R environment using the MASS and bbmle (R Core Team, 2013) packages.

\section{Results}

A total of 1,222 specimens were collected from all 18 sampled sites, representing nine species of Plusiinae (Table 1 ). By far, $C$. includens was the most abundant and dominant species found in our data set, comprising $85 \%(n=1051)$ of all specimen records. Other abundant species were recorded only in selected sample sites, such as Argyrogramma verruca (Fabricius, 1794) (n=76), Rachiplusia nu (Guenée, 1852) (n=73), and Ctenoplusia oxygramma (Geyer, 1832) $(n=25)$. All other species were only recorded by one or a few specimens (Table 2 ). 
In regard to species composition, our results clearly evidence an ordination of sites according to latitude, thus reflecting a species turnover along the gradient (Figure 2). This ordination model explains $48 \%$ of the total variability in the data (first two axes with eigenvalues of 0.41 and 0.23 , respectively). Consequently, the mean annual temperature revealed a significant correlation with the ordination produced from species composition (Table 3). Precipitation and size of corn crops also showed significant correlations but with lower $\mathrm{R}^{2}$ values, while the sizes of soybean, pasture and native areas showed no significant correlations (Table 4).

When analyzed individually, the abundance of $C$. includens showed a particular difference compared to the results obtained from the whole assemblages. The size of pasture showed to be variable that best explains the abundance of $C$. includens. Thus, sites with larger pasture crops were found to have lower abundance of the species. Also, both temperature and precipitation presented positive correlation with

Table 2

Total abundance of Plusiinae species recorded at each collection site. T - Trap (1 - predominant native area, 2 - predominant crop area);

\begin{tabular}{|c|c|c|c|c|c|c|c|c|c|c|}
\hline Local & $\mathrm{T}$ & $\begin{array}{l}\text { Agrapha } \\
\text { ahenea }\end{array}$ & $\begin{array}{c}\text { Argyrogramma } \\
\text { verruca }\end{array}$ & $\begin{array}{c}\text { Autoplusia } \\
\text { egena }\end{array}$ & $\begin{array}{c}\text { Chrysodeixis } \\
\text { includens }\end{array}$ & $\begin{array}{l}\text { Ctenoplusia } \\
\text { oxygramma }\end{array}$ & $\begin{array}{c}\text { Melanographa } \\
\text { biloba }\end{array}$ & $\begin{array}{l}\text { Mouralia } \\
\text { tinctoides }\end{array}$ & $\begin{array}{c}\text { Rachiplusia } \\
n u\end{array}$ & $\begin{array}{l}\text { Trichoplusia } \\
\text { ni }\end{array}$ \\
\hline Alegre & 1 & 1 & 0 & 1 & 1 & 2 & 0 & 0 & 2 & 1 \\
\hline Alegre & 2 & 0 & 0 & 0 & 6 & 13 & 0 & 0 & 0 & 0 \\
\hline Bage & 1 & 0 & 0 & 0 & 3 & 0 & 4 & 0 & 8 & 0 \\
\hline Bage & 2 & 0 & 0 & 0 & 1 & 0 & 6 & 0 & 10 & 0 \\
\hline Londrina & 1 & 0 & 0 & 0 & 77 & 0 & 0 & 0 & 4 & 0 \\
\hline Londrina & 2 & 0 & 1 & 0 & 29 & 0 & 1 & 0 & 2 & 0 \\
\hline Passo & 1 & 0 & 0 & 0 & 17 & 2 & 0 & 0 & 29 & 0 \\
\hline Passo & 2 & 0 & 0 & 0 & 34 & 2 & 3 & 0 & 18 & 0 \\
\hline Petrolina & 1 & 0 & 0 & 0 & 3 & 2 & 0 & 1 & 0 & 0 \\
\hline Petrolina & 2 & 0 & 0 & 0 & 10 & 0 & 0 & 0 & 0 & 0 \\
\hline Planaltina & 1 & 0 & 0 & 0 & 76 & 0 & 0 & 0 & 0 & 0 \\
\hline Planaltina & 2 & 0 & 0 & 0 & 14 & 1 & 0 & 0 & 0 & 0 \\
\hline Rio & 1 & 0 & 54 & 0 & 213 & 1 & 0 & 0 & 0 & 0 \\
\hline Rio & 2 & 0 & 14 & 0 & 3 & 2 & 0 & 0 & 0 & 0 \\
\hline Santarem & 2 & 0 & 7 & 0 & 297 & 0 & 0 & 0 & 0 & 0 \\
\hline Sinop & 2 & 0 & 0 & 0 & 255 & 0 & 0 & 0 & 0 & 0 \\
\hline Uberaba & 1 & 0 & 0 & 0 & 11 & 0 & 0 & 0 & 0 & 0 \\
\hline Uberaba & 2 & 0 & 0 & 0 & 1 & 0 & 0 & 0 & 0 & 0 \\
\hline
\end{tabular}

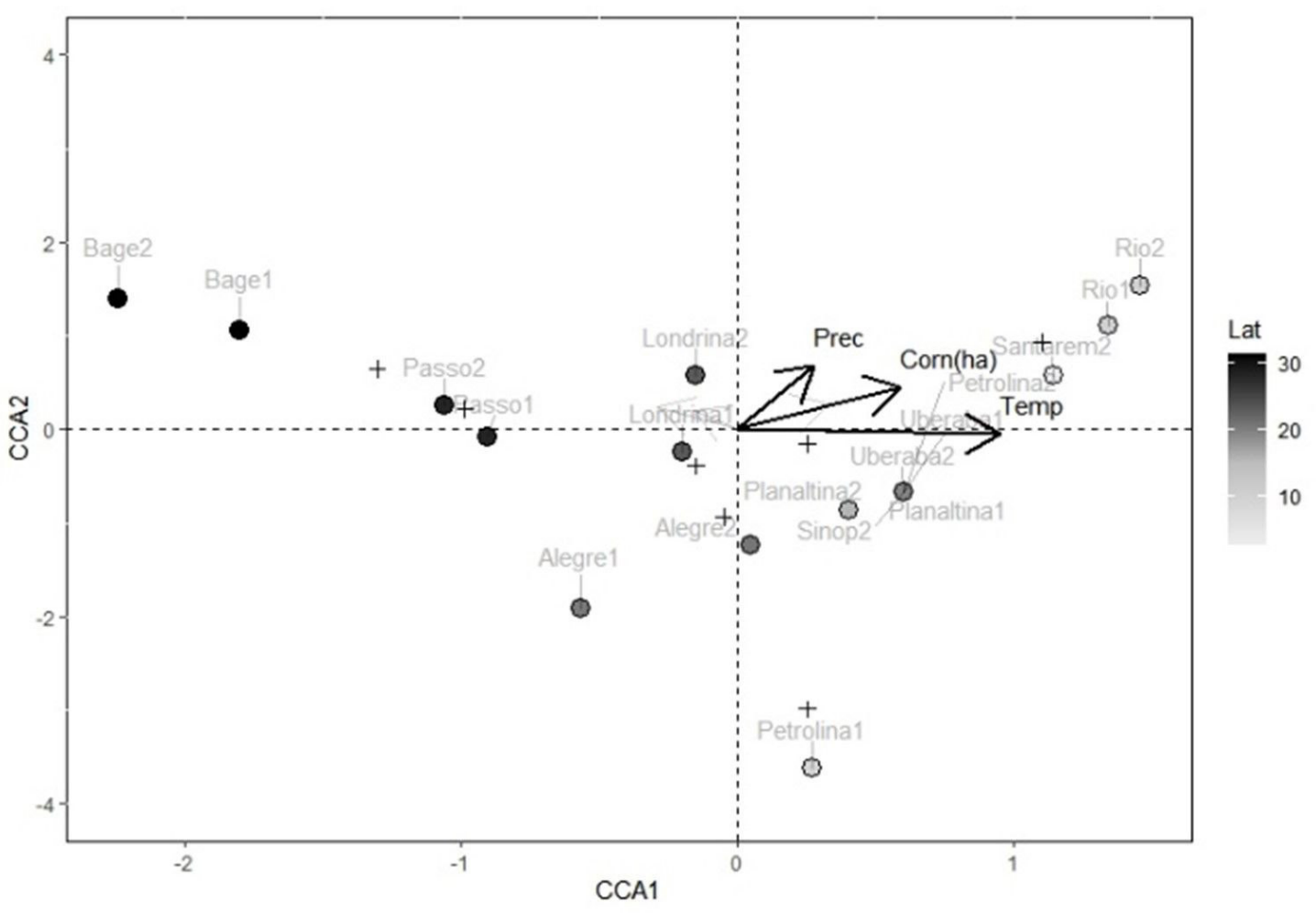

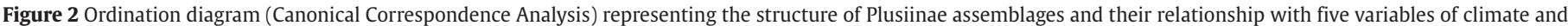

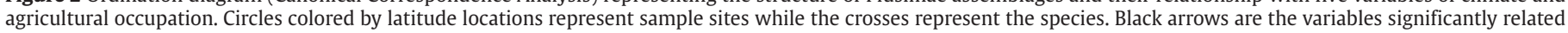

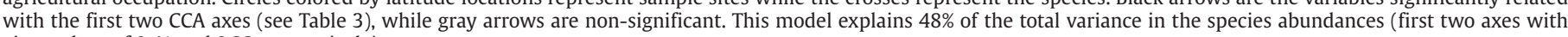
eigenvalues of 0.41 and 0.23 , respectively). 
Table 3

Correlations between the climate and agricultural occupation variables and the two first axis of the Canonical Correspondence Analysis. Temp $\left({ }^{\circ} \mathrm{C}\right)$ - Average Annual Temperature; Prec (mm) - Annual Precipitation; Soybean, Corn, Pasture and Native areas were measured in hectares, within a $400 \mathrm{~m}$ buffer radius.

\begin{tabular}{lcccc}
\hline & CCA1 & CCA2 & $\mathrm{R}^{2}$ & $\mathrm{p}$ \\
\hline Temp & 0.99 & -0.03 & 0.79 & 0.001 \\
Prec & 0.43 & 0.90 & 0.42 & 0.031 \\
Soybean & 0.81 & 0.58 & 0.15 & 0.336 \\
Corn & 0.83 & 0.56 & 0.47 & 0.018 \\
Pasture & -0.80 & 0.59 & 0.12 & 0.433 \\
Native & -0.65 & 0.76 & 0.06 & 0.694 \\
\hline
\end{tabular}

Table 4

Predictive power of climate and agricultural occupation variables on the abundance variation of Chrysodeixis includens, evaluated in scale of $400 \mathrm{~m}$. Temp: Average Temperature; Temp $\left({ }^{\circ} \mathrm{C}\right)$ - Average Annual Temperature; Prec (mm) - Annual Precipitation; Soybean, Corn, Pasture and Native areas were measured in hectares, within a $400 \mathrm{~m}$ buffer radius. $\triangle \mathrm{AICc}$ - difference between the models; df - degrees of freedom; w- weight of Akaike; AICc - Corrected Akaike information criterion; C - Correlation Polarity

\begin{tabular}{lccccc}
\hline & \multicolumn{5}{c}{ Chrysodeixis includens } \\
\cline { 2 - 6 } & $\Delta$ AICc & df & weight & AIC & C \\
\hline Pasture & 0 & 3 & 0.3302 & 170.71 & - \\
Temp & 0.3 & 3 & 0.2909 & 170.96 & + \\
Prec & 0.6 & 3 & 0.2501 & 171.26 & + \\
Corn & 3.8 & 3 & 0.049 & 174.52 & \\
Soybean & 3.9 & 3 & 0.0481 & 174.56 & \\
Null & 5.1 & 2 & 0.0255 & 176.76 & \\
Native & 8 & 3 & 0.0062 & 178.67 & \\
\hline
\end{tabular}

species abundance, with model adjustments significantly better than the null model. The size of soybean and corn crops, and natural areas revealed models without any predictive power (Table 4 ).

\section{Discussion}

General abundance and number of species

Recent literature reports that $C$. includens has become the most abundant species in agricultural ecosystems in the Americas (Lafontaine and Poole, 1991; Moscardi et al., 2012), although it is being increasingly replaced by $R . n u$ in the southern part of the country (Moraes et al., 1991; Specht \& Corseuil, 2002; Specht et al., 2005). Our results strongly support this distribution pattern.

The total richness of Plusiinae species recorded in this experiment is similar the results of other studies in Brazil (Link, 1977; Specht and Corseuil, 2002; Specht et al., 2005). However, we expected to record a greater number of species, given the broad geographic scale sampled in this study. According to the literature, A. verruca, $C$. includens, $C$. oxygramma, $R$. nu and $T$. ni were already assigned as pest species somewhere in the Americas (Herzog, 1980; Kogan, 1981; Lafontaine and Poole, 1991; Formentini et al., 2015; Specht et al., 2015; 2019). Despite that fact, only $C$. includens showed large and distinct abundances in most of the sample sites. Thus, it is possible that the agricultural activities are suppressing the otherwise common non-pest species populations, such as Mouralia tinctoides (Guenée, 1852), Enigmogramma admonens (Walker, 1957), Enigmogramma feisthameli(Guenée, 1852), Notioplusia illustrata (Guenée, 1852) (Lafontaine and Poole, 1991). However, species like $A$. egena (Guenée, 1852), which are found on cultivated varieties, showed very reduced populations, probably because their niches are dominated by other, more abundant species such as $C$. includens and $R$. nu.
Also, only a single specimen of $T$. $n i$ was collected in the course of this experiment. This species is usually very common in light traps similar to the ones employed in this study (Riherd and Wene, 1955; Graham et al., 1964), and has been ranked among the most abundant species in the United States (Riherd and Wene, 1955; Shorey et al., 1962; Harding, 1976) and is also largely abundant in some places in Brazil (Specht et al., 2019). It is likely that this is a result of the specific agricultural landscape sampled in this study. Trichoplusia ni has a preference for Brassicaceae in different regions of the world and does not seem to develop very well in crops like soybean, beans and corn (Liu et al., 1988; Specht et al., 2019). Therefore, despite of its high degree of polyphagy, Trichoplusia nican only be rarely seen in natural landscapes or in agricultural ecosystems such as those sampled here.

\section{Composition of assemblages}

It is widely known that variables such as latitude, temperature, and landscape can alter arthropod assemblages in the natural environments (Andow, 1991; Lindenfors et al., 2007). However, in terms of assemblages including some pest species, these relationships have not been thoroughly investigated.

Our data has demonstrated that climate variables prevails as the most important variables influencing the composition of Plusiinae through a wide latitudinal gradient. This result contradicted our expectations mainly because the pest species also exhibits a turnover pattern along the latitudinal gradient, thus similarly inhabiting both natural and agricultural landscapes at similar latitudinal sites. Therefore, a single factor such as temperature may have a positive and negative influences on distinct species, thus playing a major role on species' turnover along latitudinal gradients. This is likely the case of $R$. $n u$, one of the most common pest species found in southern Brazil, Uruguay, Argentina and Paraguay (Pereyra, 1994; Valverde, 2007; Barrionuevo et al., 2012; Luz et al., 2015). The distribution of this species, limited to the south and southeast of Brazil, is similar to the distribution of its congener, Rachiplusia ou (Guenée, 1852), a species restricted to the northern hemisphere. Rachiplusia ou rarely occurs during the warmer months of the year and shows a slow rise in population from the onset of autumn (Alford and Hammond, 1982). Evidently, both Rachiplusia species are adapted to subtropical environments, being one of the prime causes of economic losses in these regions. Besides, several species of Plusiinae are not able to tolerate temperatures under $0{ }^{\circ} \mathrm{C}$ and some may even exhibit migratory behavior in parts of North America to avoid such low temperatures (Blau, 1981; Mason et al., 1989; Lafontaine and Poole, 1991; Wagner et al., 2011; Moscardi et al., 2012).

Additionally, the composition of Plusiinae assemblages is also strongly correlated with precipitation and the size of corn crops. Precipitation is a relevant parameter in structuring many assemblages of insects (Wu et al., 2011), and it tends to be even more important when sample sites includes places of semi-arid conditions (Zhu et al., 2014). Therefore, our results suggest that this assemblages of Plusiinae also include species that have preferences for habitats with greater or lesser rainfall indexes. As some of these species might have economic relevance to some crop species, it would be useful for agricultural managers to account for local climatic conditions in pest population management programs.

On the other hand, the lack of significance found for the effect of variables representing agricultural occupation on structuring the Plusiinae assemblages reveals that the pest species can also be found in similar abundance in natural ecosystems. Furthermore, several Plusiinae species are highly polyphagous (Eichlin and Cunningham, 1978; Lafontaine and Poole, 1991; Wagner et al., 2011), which allows them to use suboptimal hostplants when the preferred species (e.g. 
crop species) is momentarily absent, instead of traveling long distances trough a latitudinal gradient. In this study, only the size of corn crops showed a significant effect on assemblages probably due to the use of this species at some sample sites in rotation systems. We hypothesize that, when present, crop rotations provides access to viable hostplants for longer periods during each year, thus resulting in higher rates of annual offspring and larger populations (Specht et al., 2019).

There are of course a myriad of other phenomena besides the ones evaluated in the present study, which can affect the abundances of Plusiinae species, including natural enemies and agricultural management methods (Cammell and Knight, 1992; Lima et al., 2009). Chrysodeixis includens, $R$. nu and $C$. oxygramma are also negatively affected by pathogens, parasitoids and predators (Harding, 1976; Maruyama, et al., 2001; Parra et al., 2002; Sosa-Gómez et al., 2003) and are positively influenced by the use of nonselective insecticides (Ferron, 1978; Sosa-Gómez et al., 2003). Additionally, migration routes, such as those traveled by $A$. verruca, $C$ includens, $C$. oxygramma and T. $n I$ ) in the northern hemisphere from low to high latitudinal sites in the end of the spring and beginning of summer (e.g. Ferguson et al., 1991; Lafontaine and Poole, 1991), are still unknown to occur in southern hemisphere. Besides, temperature conditions in most of South America is rarely below freezing, which is a factor influencing this kind of behavior in insects.

\section{Factors that influenced the abundance of $C$ includens}

As mentioned before, $C$. includens is the dominant pest Lepidoptera in most cultivated crops across the Americas (Moraes et al., 1991; Marsaro Jr. et al., 2010). However, although agricultural activities supply the bulk of food resources for this species, abiotic factors such as temperature and precipitation again strongly determined its abundance. Similar to the majority of tropical insects (Oliveira and Frizzas, 2008), larger populations of the species are found where the mean annual temperature and precipitation are higher. In South America, species' abundance declines towards the south, while in the north and centerwest this pest is considered a primary pest (Bueno et al., 2013). In the United States, this species is unable to develop under $0{ }^{\circ} \mathrm{C}$; and when the temperature plummets to $10^{\circ} \mathrm{C}$, the species migrates to warmer locales in the country (Mason et al., 1989; Moscardi et al., 2012). This behavior, however, is yet to be reported in South America.

Clearly, host plant availability should also play a crucial role in explaining some of the variation observed in the abundance of C. includens. The species has been reported in 175 different host plants (Baldin et al., 2014; Specht et al., 2015), but with a strong preference for soybean (Khalsa et al., 1979; Formentini et al., 2015; Specht et al., 2019). Such preference can explain the high population indices in parts of the country where soybean is heavily cultivated. But despite of that, we could not find any significant relationship between species abundance and size of soybean crops. Instead, the size of pasture crops revealed the best model that explains species abundance, but in a negative relationship. Similarly, Almeida et al. (2014) also reported the rarity of this species in an Amazon area converted in pasture. These results suggest that pasture landscapes are very restrictive to the presence of $C$. includens, even in places of high temperature and precipitation such as de Amazon biome.

Finally, a previous study sampling semiloopers in Central Brazil detected a significant drop in Plusiinae population across three consecutive crop seasons (Santos et al., 2017). In this study, the 2015/2016 crop in the same area revealed that the number of specimens collected by the same authors fell below one-tenth of the number collected during the first crop season. Therefore, the total Plusiinae abundance and richness recorded in this study were clearly influenced by the El Niño effect, which caused population declines of many species associated with agricultural systems and in many places in Brazil (Santos et al., 2017; Piovesan et al. 2019). New samplings at those sample sites are therefore necessary to record the actual population size of these species and maybe evaluate the role of El Niño on the decreasing of pest species populations.

\section{Acknowledgments}

We are grateful to all of those involved with field collections of specimens used in this study: Adriano Q. Mesquita, Américo I. Ciociola Júnior, André L. Filipiake, Antônio C.S. Araújo, Balbino A. Evangelista, Brenda M. Moreira, Daniel B. Fragoso, Dirceu Pratissoli, Erivaldo A. Santos, Felipe O. Mateus, Harry Ebert, João B.G. Santos Filho, Jorge U. P. Corrêa, José A. Teston, José R. Carvalho, José S. Zanúncio Júnior, Leonardo Mardgan, Maicon Coradini, Marco A.P. Silva, Marcos R.O. Serpa, Murilo Fazolin, Naylor B. Perez, Oriverto Tonon, Paulo R.V.S. Pereira, Rafael M. Pitta, Rodison N. Sisti, Sandra M.M. Rodrigues, Tiago C. C. Lima and Wilson Pozenato. Conselho Nacional de Desenvolvimento Científico e Tecnológico - CNPq: AS (processo no. 306601/2016-8); MMC (processo 302084/2017-7) for fellowships and research funds (processo №. 403376/2013-0), and Empresa Brasileira de Pesquisa Agropecuária Embrapa (SEG MP2 nº 02.13.14.006.00.00) partially funded this study. Coordenação de Aperfeiçoamento de Pessoal de Nível Superior - CAPES (Edital Capes-Embrapa nํㅜㄴ 15/2014 - Proposta 92) provided fellowships to EC and SRS. We are also grateful to ICMBio and MMA for the Authorizations for Scientific Activities (SISBIO nº 48218-3 and 38547/6).

\section{Conflicts of interest}

The authors declare that they have no conflict of interest.

\section{Author contributions statement}

AS, EC and MMC are responsible for the study conception and sampling design, supervision of the project and also contributed to the data analysis and to the writing of the manuscript. SRS contributed to the study conception, carried out the field and laboratory works. EC and SRS performed data analysis and wrote the manuscript with input from the other authors. All authors read, corrected and approved the manuscript.

\section{References}

Alford, A. R., Hammond Jr, A. M., 1982. Plusiinae (Lepidoptera: Noctuidae) populations in Louisiana soybeans ecosystems as determined with looplure-baited traps. J. Econ. Entomol. 75 (4), 647-650. https://doi. org/10.1093/jee/75.4.647.

Almeida, L. P., Specht, A., Teston, J. A., 2014. Fauna of Noctuidae (Lepidoptera: Noctuoidea) in a pasture area in Altamira, Eastern Amazon, Pará, Brazil. Braz. J. Biol. 74 (4), 983-990. https://doi. org/10.1590/1519-6984.07713.

Andow, D. A., 1991. Vegetational diversity and arthropod population response. Annu. Rev. Entomol. 36, 561-586. https://doi.org/10.1146/ annurev.en.36.010191.003021.

Baldin, E. L. L., Lourenção, A. L., Schlick-Souza, E. C., 2014. Outbreaks of Chrysodeixis includens (Walker) (Lepidoptera: Noctuidae) in common bean and castor bean in São Paulo State, Brazil. Bragantia 73 (4), 458-465. https://doi.org/10.1590/1678-4499.0277. 
Barbut, J., 2008. Révision du genre Rachiplusia Hampson, 1913 (Lepidoptera, Noctuidae, Plusiinae). Bull. Soc. Entomol. Fr. 113 (4), 445-452.

Barrionuevo, M. J., Murua, M. G., Goane, L., Meagher, R., Navarro, F., 2012. Life table studies of Rachiplusia nu(Guenée) and Chrysodeixis (= Pseudoplusia) includens (Walker) (Lepidoptera: Noctuidae) on artificial diet. Fla. Entomol. 95 (4), 944-951.

Blau, W. S., 1981. Latitudinal variation in the life histories of insects occupying disturbed habitats: a case study, In: Denno, R.F., Dingle, H. (Eds.), Insect Life History Patterns: Habitat and Geographic Variation. Springer, New York, pp. 75-95.

Bueno, A. F., Paula-Moraes, S. V., Gazzoni, D. L., Pomari, A. F., 2013. Economic thresholds in soybean-integrated pest management: old concepts, current adoption, and adequacy. Neotrop. Entomol. 42 (5), 439-447. https://doi.org/10.1007/s13744-013-0167-8.

Burnham, K. P., Anderson, D. R., 2003. Model Selection and Multimodel Inference: A Practical Information-Theoretic Approach. SpringerVerlag, New York. https://doi.org/10.1007/b97636.

Cammell, M. E., Knight, J. D., 1992. Effects of climatic change on the population dynamics of crop pests, In: Begon, M., Fitter, A.H., Macfadyen, A., (Eds.), Advances in Ecological Research: The Ecological Consequences of Global Climate Change. Academic Press, London, pp. 117-162.

Dover, J., Settele, J., 2009. The influences of landscape structure on butterfly distribution and movement: a review. J. Insect Conserv. 13, 3-27. https://doi.org/10.1007/s10841-008-9135-8.

Eichlin, T. D., Cunningham, H. B., 1978. The Plusiinae (Lepidoptera: Noctuidae) of America North of Mexico, emphasizing genitalia and larval morphology. USDA Tecn. Bull. 1567, 1-122.

Ferguson, D. C., Hilburn, D. J., Wright, B., 1991. The Lepidoptera of Bermuda: Their food plants, biogeography, and means of dispersal. Mem. Entomol. Soc. Can. 123 (S158), 3-105. https://doi.org/10.4039/ entm123158fv.

Ferron, P., 1978. Biological control of insect pests by entomogenous fungi. Annu. Rev. Entomol. 23, 409-442. https://doi.org/10.1146/ annurev.en.23.010178.002205.

Formentini, A. C., Sosa-Gómez, D. R., Paula-Moraes, S. V., Barros, N. M., Specht, A., 2015. Lepidoptera (Insecta) associated with soybean in Argentina, Brazil, Chile and Uruguay. Cienc. Rural 45 (12), 2113-2120. https://doi.org/10.1590/0103-8478cr20141258.

Frost, S. W., 1957. The Pennsylvania Insect Light Trap. J. Econ. Entomol. 50 (3), 287-292. https://doi.org/10.1093/jee/50.3.287.

Graham, H. M., Glick, P. A., Martin, D. F., 1964. Nocturnal activity of adults of six lepidopterous pests of cotton as indicated by lighttrap collections. Ann. Entomol. Soc. Am. 57 (3), 328-332. https:// doi.org/10.1093/aesa/57.3.328.

Harding, J. A., 1976. Seasonal occurrence, parasitism and parasites of cabbage and soybean loopers in the lower Rio Grande Valley. Environ. Entomol. 5 (4), 672-674. https://doi.org/10.1093/ee/5.4.672.

Herzog, D. C. 1980. Sampling soybean looper on soybean. In: Kogan, M., Herzog, D.C. (Eds.), Sampling Methods in Soybean Entomology. New York, Springer. pp. 141-168. https://doi.org/10.1007/978-14612-9998-1_7.

Hijmans, R. J., Cameron, S. E., Parra, J. L., 2006. Worldclim Global Climate Layers Version 1.4. Available in: http://www.worldclim.org (accessed 24 November 2019).

Instituto Brasileiro de Geografia e Estatistica - IBGE, 2004. Mapa de biomas do Brasil. Available in: http://mapas.ibge.gov.br/biomas2/ viewer.htm (accessed 13 November 2019).

Khalsa, M. S., Kogan, M., Luckmann, W. H., 1979. Autographa precationis in relation to soybean: life history, and food intake and utilization under controlled conditions. Environ. Entomol. 8 (1), 117-122. https://doi.org/10.1093/ee/8.1.117.
Kogan, M., 1981. Dynamics of insect adaptations to soybean: impact of integrated pest management. Environ. Entomol. 10 (3), 363-371. https://doi.org/10.1093/ee/10.3.363.

Lafontaine, J. D., Poole, R. W., 1991. Noctuoidea: Noctuidae (part.): Plusiinae. Washington, The Wedge Entomological Research Foundation, 182 p. [Série: The moths of America North of Mexico, including Greenland; fasc. 25.1].

Lima, E. A. B. F., Ferreira, C. P., Godoy, W. C., 2009. Ecological modeling and pest population management: a possible and necessary connection in a changing World. Neotrop. Entomol. 38 (6), 699-707. https:// doi.org/10.1590/S1519-566X2009000600001.

Lindenfors, P., Nunn, C. L., Jones, K. E., Cunningham, A. A., Sechrest, W., Gittleman, J. L., 2007. Parasite species richness in carnivores: effects of host body mass, latitude, geographical range and population density. Glob. Ecol. Biogeogr. 16 (4), 496-509. https:// doi.org/10.1111/j.1466-8238.2006.00301.x.

Link, D., 1977. Abundância relativa de alguns Noctuidae, em armadilha luminosa, em Santa Maria, RS. Rev. Cetro Ciênc. Rurais 7 (4), 331-351.

Liu, S. H., Norris, D. M., Mart, E., 1988. Behavioral responses of female adult Trichoplusia ni to volatiles from soybeans versus a preferred host, lima bean. Entomol. Exp. Appl. 49 (1-2), 99-109. https://doi. org/10.1111/j.1570-7458.1988.tb02481.x.

Luz, P. M. C., Azevedo Filho, W. S., Specht, A., 2015. Caracterização morfológica dos estágios imaturos de Rachiplusia nu(Guenée, 1852) (Lepidoptera: Noctuidae: Plusiinae) e lista de plantas hospedeiras. Cad. Pesqui. 26, 65-76.

Marsaro Jr, A. L., Pereira, P. R. V. S., Silva, W. R., Griffel, S. C. P., 2010. Flutuação populacional de insetos-praga na cultura da soja no estado de Roraima. Rev. Acad., Ciênc. Agrár. Ambient. 8 (1), 71-76.

Maruyama, W. I., Gravena, S., Pinto, A. S., 2001. Parasitóides e Nomuraea rileyi (Farlow) Samson em lagartas desfolhadoras (Lepidoptera) na cultura da soja. Bol. Sanid. Veg., Plagas 27, 561-567.

Mason, L. J., Johnson, S. J., Woodring, J., 1989. Seasonal and ontogenetic examination of the reproductive biology of Pseudoplusia includens (Lepidoptera: noctuidae). Environ. Entomol. 18 (6), 980-985. https:// doi.org/10.1093/ee/18.6.980.

Moraes, R. R., Loeck, A. E., Belarmino, L. C., 1991. Flutuação populacional de Plusiinae e Anticarsia gemmatalis Hübner, 1818 (Lepidoptera: Noctuidae) em soja no Rio Grande do Sul. Pesqui. Agropecu. Bras. 26 (1), 51-56.

Moscardi, F., Bueno, A. F., Sosa-Gómez, D. R., Roggia, S., Hoffmann-Campo, C. B., Pomari, A. F., Corso, I. C., Yano, S. A. C., 2012. Soja - Manejo integrado de insetos e outros artrópodes-praga, In: HoffmannCampo, C. B., Corrêa-Ferreira, B. S., Moscardi, F. (Eds.), Artrópodes que atacam as folhas da soja. Embrapa, Brasília, pp. 214-334.

Munguira, M. L., García-Barros, E., Cano, J. M., 2009. 5 - Butterfly herbivory and larval ecology. In: Settele, J., Shreeve, T., Konvi ka, M., Dyck, H. V. (Eds.), Ecology of Butterflies in Europe. Cambridge University Press, Cambridge, pp. 43-54.

National Oceanic and Atmospheric Administration - NOAA, 2020. Available in: http://www.cpc.ncep.noaa.gov/products/analysis monitoring/lanina/enso evolution-statusfcsts-web.pdf/, (accessed 20 December 2020).

Oliveira, C. M., Frizzas, M. R., 2008. Insetos de Cerrado: distribuição estacional e abundância, Embrapa Cerrados, Planaltina, DF, Boletim de Pesquisa e Desenvolvimento, 216, pp. 1-26.

Oliveira, U., Vasconcelos, M. F., Santos, A. J., 2017. Biogeography of Amazon birds: rivers limit species composition, but not areas of endemism. Sci. Rep. 7 (1), 2992. https://doi.org/10.1038/s41598-017-03098-w.

Parra, J. R. P., Botelho, P. S. M., Corrêa-Ferreira, S., Bento, J. M. S., 2002. Controle biológico no Brasil: parasitoides e predadores. Manole, São Paulo. 
Pereyra, P. C., 1994. Efecto de la edad de las hojas de soja sobre el crecimiento y reproducción de Rachiplusia nu (Lepidoptera: noctuidae). Ecol. Austral 4 (1), 41-47.

Piovesan, M., Carneiro, E., Specht, A., Casagrande, M. M., 2019. Where and when? How phenological patterns of armyworm moths (Lepidoptera: Noctuidae) change along a latitudinal gradient in Brazil. Bull. Entomol. Res. 109 (4), 490-499. https://doi.org/10.1017/ S0007485318000822.

Poole, R. W., 1989. Noctuidae, In: Hepner, J.B. (Ed.), Lepidopterorum Catalogus - Fascicle 118. Part. 1, 2 and 3. Brill, New York.

Primavesi, O., Arzabe, C., Pedreira, M. S., 2007. Mudanças climáticas: visão tropical integrada das causas, dos impactos e de possíveis soluções para ambientes rurais ou urbanos. Embrapa, Brasília, DF, Documentos 70, pp. 1-200.

R Core Team 2013. R: A Language and Environment for Statistical Computing. R Foundation for Statistical Computing, Vienna. Available in: http://www.R-project.org/ (accessed 13 November 2019).

Rambaldi, D. M., Oliveira, D. A. S., 2003. Fragmentação de ecossistemas: causas, efeitos sobre a biodiversidade e recomendações de políticas públicas. MMA/SBF, Brasília.

Ribeiro, D. B., Batista, R., Prado, P. I., Brown Jr, K. S., Freitas, A. V. L., 2012. The importance of small scales to the fruit-feeding butterfly assemblages in a fragmented landscape. Biodivers. Conserv. 21, 811-827. https://doi.org/10.1007/s10531-011-0222-x.

Riherd, P. T., Wene, G. P., 1955. A study of moths captured at a light trap at Weslaco, Texas. J. Kans. Entomol. Soc. 28 (3), 102-107.

Robinet, C., Roques, A., 2010. Direct impacts of recent climate warming on insect populations. Integr. Zool. 5 (2), 132-142. https://doi. org/10.1111/j.1749-4877.2010.00196.x.

Santos, S. R., Specht, A., Carneiro, E., Paula-Moraes, S. V., Casagrande, M. M., 2017. Interseasonal variation of Chrysodeixis includens (Walker, [1858]) (Lepidoptera: Noctuidae) populations in the Brazilian Savanna. Rev. Bras. Entomol. 61 (4), 294-299. https://doi. org/10.1016/j.rbe.2017.06.006.

Shorey, H. H., Andres, L., Hale, R. L., 1962. The biology of Trichoplusia ni (Lepidoptera: Noctuidae). I. Life history and behavior. Ann. Entomol. Soc. Am. 55 (5), 591-597. https://doi.org/10.1093/aesa/55.5.591.

Silva-Brandão, K. L., Ribeiro, D. B., Monteiro, M., Brito, A. J. A. O., Freitas, A. V. L., 2016. 12 - The influence of agricultural and forest landscapes on the diversity of Lepidoptera. In Gheler-Costa, C., Lyra-Jorge,
M. C., Verdade, L. (Eds.) Biodiversity in agricultural landscapes of Southeastern Brazil. Berlin, De Gruyter Open, pp. 190-205. https:// doi.org/10.1515/9783110480849-014.

Sosa-Gómez, D. R., Delpin, K. E., Moscardi, F., Nozaki, M. H., 2003. The impact of fungicides on Nomuraea rileyi(Farlow) Samson epizootics and on populations of Anticarsia gemmatalis Hübner (Lepidoptera: Noctuidae), on soybean. Neotrop. Entomol. 32 (2), 287-291. https:// doi.org/10.1590/S1519-566X2003000200014.

Specht, A., Corseuil, E., 2002. Diversidade dos noctuídeos (Lepidoptera, Noctuidae) em Salvador do Sul, Rio Grande do Sul, Brasil. Rev. Bras. Zool. 19 (Suppl.1), 281-298. https://doi.org/10.1590/S010181752002000500022.

Specht, A., Paula-Moraes, S. V., Sosa-Gómez, D. R., 2015. Host plants of Chrysodeixis includens (Walker) (Lepidoptera, Noctuidae, Plusiinae). Rev. Bras. Entomol. 59 (4), 343-345. https://doi.org/10.1016/j. rbe.2015.09.002.

Specht, A., Sosa-Gómez, D. R., Roque-Specht, V. F., Valduga, E., Gonzatti, F., Schuh, S. M., Carneiro, E., 2019. Biotic potential and life tables of Chrysodeixis includens (Lepidoptera: Noctuidae), Rachiplusia nu, and Trichoplusia ni on soybean and forage turnip. J. Insect Sci. 19 (4), 1-8. http://dx.doi.org/10.1093/jisesa/iez072.

Specht, A., Teston, J. A., Di Mare, R. A., Corseuil, E., 2005. Noctuídeos (Lepidoptera, Noctuidae) coletados em quatro áreas estaduais de conservação do Rio Grande do Sul, Brasil. Rev. Bras. Entomol. 49 (1), 130-140. https://doi.org/10.1590/S0085-56262005000100015.

Valverde, L., 2007. Abundancia y distribución de los huevos de las principales especies de lepidópteros noctuidos plagas en el cultivo de soja en Tucumán. Bol. Sanid. Veg., Plagas 33 (2), 163-168.

Wagner, D. L., Schweitzer, D. F., Sullivan, J. B., Reardon, R. C., 2011. Owlet caterpillars of eastern North America. Princeton University Press, New Jersey.

Wu, Z., Dijkstra, P., Koch, G. W., Peñuelas, J., Hungate, B. A., 2011. Responses of terrestrial ecosystems to temperature and precipitation change: a meta-analysis of experimental manipulation. Glob. Change Biol. 17, 927-942. https://doi.org/10.1111/j.1365-2486.2010.02302.x.

Zhu, H., Wang, D., Wang, L., Fang, J., Sun, W., Ren, B., 2014. Effects of altered precipitation on insect community composition and structure in a meadow steppe. Ecol. Entomol. 39, 453-461. https:// doi.org/10.1111/een.12120. 